\title{
УДК 504.5:656.225.073.436
}

\author{
Ю. В. ЗЕЛЕНЬКО ${ }^{*}$, М. В. КАЛИМБЕТ ${ }^{* *}$, Д. В. ФЕСЕНКО ${ }^{*}$
}

${ }^{1 *}$ Каф. «Хімія та інженерна екологія», Дніпровський національний університет залізничного транспорту імені академіка В. Лазаряна, вул. Лазаряна, 2, Дніпро, Україна, 49010, тел. +38 (067) 77404 64, ел. пошта j.v.zelenko@ gmail.com, ORCID 0000-0001-5551-0305

${ }^{2 *}$ Каф. «Хімія та інженерна екологія», Дніпровський національний університет залізничного транспорту імені академіка В. Лазаряна, вул. Лазаряна, 2, Дніпро, Україна, 49010, тел. +38 (093) 431 19 69, ел. пошта kalimbet.nicolay@ gmail.com

$3^{*}$ Каф. «Хімія та інженерна екологія», Дніпровський національний університет залізничного транспорту імені академіка В. Лазаряна, вул. Лазаряна, 2, Дніпро, Україна, 49010, тел. +38 (073) 17690 02, ел. пошта darya.fesenko1998@ gmail.com

\section{ВПРОВАДЖЕННЯ ЗАХОДІВ ЩОДО ЛІКВІДАЦІї НАСЛІДКІВ АВАРІЙ ПРИ ПЕРЕВЕЗЕННІ НЕБЕЗПЕЧНИХ ВАНТАЖІВ}

У статті розглядаються проблеми під час перевезення небезпечних вантажів та під час ліквідації аварійних наслідків. Запропоновані заходи по вирішенню цих проблем. Мета дослідження - удосконалення процедури перевезення небезпечних вантажів залізничним транспортом та ліквідаційних заходів, а також зменшення часових витрат на ліквідацію аварійних наслідків при перевезенні небезпечних вантажів залізничним транспортом. Методика. В цій статті детально описується запропоновані авторами пропозиції щодо вдосконалення процедури перевезення небезпечних вантажів, та ліквідаційних заходів в правовому полі, шляхом перегляду повноважень співробітників, а також шляхом розробки та використання універсального сорбенту з композитних матеріалів. Авторами пропонується розробка універсального сорбенту та впровадження його на залізничному транспорті. Наукова новизна полягає у створенні універсального сорбенту, який матиме змогу, як одного з ліквідаційних заходів при аварійних ситуаціях під час перевезення небезпечних вантажів залізничним транспортом. Практична значимість. В Україні, на залізничному транспорті є сорбенти для ліквідації аварій, їх дуже багато, але один сорбент можна використовувати тільки для ліквідації конкретного класу небезпеки, а наш універсальній сорбент, можна буде використати для ліквідації декількох класів небезпечних вантажів. Автори пропонують його прикріпити до поїзда, що дасть змогу зразу приступити до локалізації розливу до прибуття аварійно-відновного поїзда, та таким чином зменшить дорогоцінний час на ліквідаційні заходи. Також розширення повноважень деяких підрозділів дозволить зменшити кількість аварійних ситуацій, та наслідки під час локалізації та ліквідацій аварій при перевезенні небезпечних вантажів.

Ключові слова: екологічні технології; небезпечні вантажі; локалізація аварій; спеціальне навчання; універсальний сорбент; аварійно-відновні поїзди

\section{Вступ}

В даний час в багатьох країнах світу, в тому числі державах Євросоюзу та Україні, зростає розуміння важливості вирішення глобальних проблем транспортних комплексів. Це, перш за все, пов'язано з вимогами підвищення безпеки та ефективності перевезень, 3 ростом мобільності суспільства, необхідністю зменшення впливу транспорту на навколишне середовище та інших.

Вплив об'єктів залізничного транспорту на природу [1] обумовлено будівництвом доріг, виробничо - господарською діяльністю підприємств, експлуатацією залізниць i рухомого складу, спалюванням великої кількості палива застосуванням пестицидів на лісових смугах і ін.

Забруднення від об'єктів залізничного транспорту [2] накладаються на фонові показники забруднень від господарсько- побутової, культурної та виробничої діяльності суспільства. Часто в районах станцій і вузлів залізничних магістралей фонові забруднення перевищують допустимі норми. Забруднення навколишнього природного середовища залежить від інтенсивності будівництва i функціонування об’єктів залізничного транспорту.

Значна кількість вантажів, перевезених залізничним транспортом, висока вантажонапруженість окремих ділянок, викликане поглибленням спеціалізації виробництв, природна тенденція до збільшення швидкостей руху, нестача засобів для придбання та своєчасного капітального ремонту рухомого складу у країнах 3 перехідною економікою та ряд інших причин обумовлюють неможливість повного виключення транспортних аварій з екологічно небезпечними вантажами. 


\section{Мета}

Метою дослідження $є$ розробка заходів та раціонального підходу до ліквідації наслідків аварій при перевезенні небезпечних вантажів.

\section{Виклад основного матеріалу}

Залізничний транспорт, зокрема його рухомий склад, справляє негативний вплив на всі ланки біосфери.

Особливої уваги 3 точки зору екологічної безпеки викликає перевезення небезпечних вантажів. Українськими залізницями перевозяться близько 98000 небезпечних вантажів, широкого спектру найменувань, які при порушенні умов перевезення і виникненні аварійних ситуацій можуть викликати різні види небезпеки: пожежо- та вибухонебезпечність, токсичну, радіаційну, інфекційну і корозійну.

Аналіз стану безпеки руху поїздів на залізничному транспорту України за період, 3 2009-2019 роки, показує, що на «катастрофи» припадає 2\% від загальної кількості транспортних подій, «серйозні інциденти» виникали у $14 \%$ випадках, а на «інциденти» припадає $84 \%$ транспортних подій.

Bce це пов'язано 3 недостатньою кваліфікацією персоналу та незадовільною забезпеченістю матеріально-технічної бази АТ «Укрзалізниця» ліквідаційними засобами. Так, згідно статистичної звітності за останні 5 років [3], кількість персоналу, що проходить спеціальне навчання 3 питань перевезення небезпечних вантажів відповідно до постанови Кабінету Міністрів України від 31.10.2007 № 1285 «Про затвердження Порядку проведення спеціального навчання працівників суб'єктів перевезення небезпечних вантажів» [4] збільшилась майже в 2 разі. Приблизно $58 \%$ робітників, $26 \%$ фахівців та $16 \%$ керівників підприємств пройшли спеціальне навчання та мають відповідні сертифікати. Так тенденція проходження працівниками залізниці спеціального навчання збільшується, але питання стосовно призначення на посади не кваліфікованого персоналу все ще залишається актуальним. Майже кожен другий працівник, що займає конкретну посаду на підприємстві, не має відповідної освіти.

На думку авторів потрібно проводити спеціальне навчання для всіх посад, що задіяні в процедурах поводження 3 небезпечними вантажами. Крім того, подібні перевезення повинні супроводжуватись спеціально навченою людиною, яка має 2 сертифікати: 1-й сертифікат, що дозволяє займатись перевезенням небезпечних вантажів, а 2-й сертифікат - дозволяе брати участь у ліквідаційних заходах наслідків аварій. Це, в цілому, підвищить безпеку перевізного процесу та зменшить кількість аварій.

Процедура проведення спеціального навчання повинна постійно контролюватись саме АТ «Укрзалізниця», як оператором інфраструктури, що надає свої колії для руху поїздів, локомотиви, вагони, і.т.п. Так вони зможуть контролювати всіх операторів, що займаються у сфері перевезення небезпечних вантажів.

Для проведення спеціального навчання АТ «Укрзалізниця» звертається, до спеціально уповноважених органів та центрів, які мають відповідних спеціалістів, ліцензії та свідоцтва Мінінфраструктури.

При цьому основний акцент має ставитись на постійну співпрацю АТ «Укрзалізниця» та відповідного Центру, що проводить спеціальне навчання 3 ціллю контролю якості надання відповідних послуг.

Сьогодні існує декілька проблем у питанні співпраці Центрів та АТ «Укрзалізниця», а саме:

- відсутня мотивація в успішному навчанні серед робітників інфраструктури;

- складний графік робочого часу та щільний графік проведення спеціального навчання;

- низька кадрова забезпеченість, пов'язана зі скрутною економічною ситуацією;

- недостатній рівень освіти за фахом;

- невідповідність слухача вимогам за віком (навчання робітників передпенсійного та пенсійного віку);

- незабезпеченість місць проведення спеціального навчання відповідною кількістю нормативних документів та посібників, зокрема у разі проведення спеціального навчання на лініях;

- недосконалий кадровий контингент у зв'язку з низькою оплатою праці;

- недосконала процедура відбору працівників для проходження спеціального навчання.

На рис. 1 представлена схематична модель, яка демонструє взаємодію підрозділів АТ «Укрзалізниця» 3 іншими суб' єктами перевезення небезпечних вантажів на залізничному транспорті.

Як видно зі схеми є замовник якому потрібно перевезти небезпечний вантаж 3 пункту А до пункту Б, і він звертається до компанії перевізника(потік А), для того щоб вона допомогла з перевезенням, а також звертається 
до АТ «Укрзалізниця» (потік Н), для перевезення небезпечних вантажів. Після звернення до компанії перевізника, ця компанія також звертається до АТ «Укрзалізниця», для обговорення деталей перевезення небезпечних вантажів, для прокладання маршруту, дати часу та багато іншого, для ознайомлення 3 вимогами до перевезення небезпечних вантажів та людей, що супроводжують їх, які висуває АТ «Укрзалізниця» (потік G). Ознайомлюється 3 вимогами які висуває Міністерство інфраструктури України (потоки D,F) та якими i не тільки, має змогу корегувати роботу АТ «Укрзалізниця» (потік Е). Після ознайомлення 3 вимогами АТ «Укрзалізниця» та Міністерства інфраструктури України компанія перевізник виконує всі ці вимоги, однією 3 яких є мати у складі спеціально навчену людину, для супроводження вантажів (потік А), що має сертифікати для перевезення небезпечних вантажів та ліквідації аварійних наслідків, $і$ для того щоб отримати можливість перевезти небезпечний вантаж 3 пункту А до пункту Б. Якщо компанія перевізника не має у штаті спеціально навченої людини для супроводження небезпечних вантажів, то вона може звернутись до компанії що займається супроводженням небезпечних вантажів (потік С). Для проведення спеціального навчання АТ «Укрзалізниця» може звернутись до компанії, що займається навчанням працівників (Потік В). Ця компанія виділяє штатного співробітника, який(ка) проводитиме спеціальне навчання співробітників. Після того як штатний працівник компанії перевізника, пройде спеціальне навчання, отримає відповідні сертифікати, та дотримається інших вимог, після чого компанія перевізник може взяти участь у перевезенні вантажу разом із АТ «Укрзалізниця» для замовника із пункту А до пункту Б, (Потік А). Потік А на схемі позначений суцільною лінією, тому що він $\epsilon$ основним потоком у схемі, усі інші потоки позначені штрих-пунктирною лінією, бо вони лише додаткові потоки, які так чи інакше впливають на потік А, або коригують його. На схемі також $\epsilon$ потік $\mathrm{K}$ який означає, лише небезпечний вантаж, який потрібно перевезти для замовника з пункту А до пункту Б.

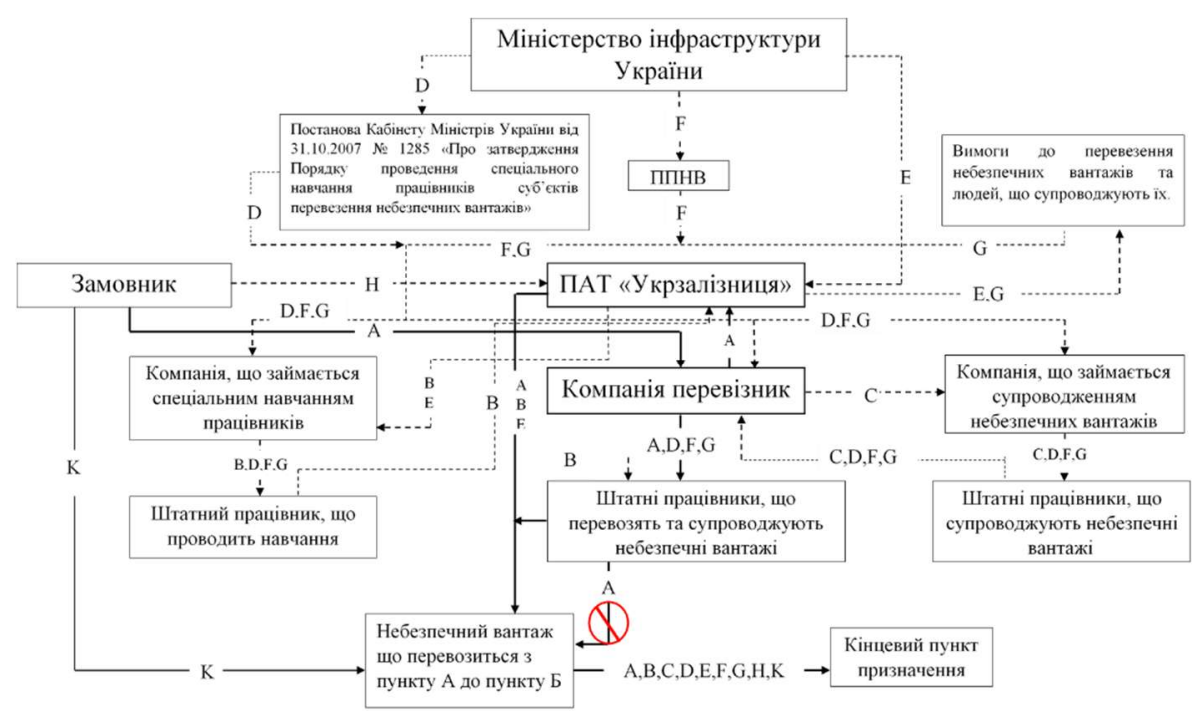

Рис. 1. Схематична модель взаємодії підрозділів АТ «Укрзалізниця» з іншими суб'єктами перевезення.

Наступною проблемою $-\epsilon$ незадовільна забезпеченість матеріально-технічної бази АТ «Укрзалізниця» ліквідаційними засобами та їх моральна невідповідність (де-які перебувають в експлуатації понад 30 років) тобто, їх устаткування й обладнання фізично й морально застаріло, а технічні рішення не відповідають сучасному рівню розвитку науки i техніки, вимогам норм і правил промислової безпеки, до того ж відсутність заходів та засобів для локалізації, та ліквідації небезпечних наслідків у разі виникнення аварійної ситуації, унеможливлюють швидке реагування, як на фізичному так і на документально-правовому рівнях.

Якщо говорити про засоби ліквідації та локалізації то треба у першу чергу згадати про аварійно-відновні поїзди я не мають повноважень для локалізації наслідків аварій при перевезенні небезпечних вантажів залізничним транспортом. На думку авторів треба на документальному рівні дозволити аварійно-відновлювальним поїздам брати участь у локалізації та ліквідації аварійних 
наслідків, до того ж оснастити поїзди необхідним обладнання для ліквідації, тому що зараз вони можуть брати участь тільки у відновленні залізничного полотна, та пропускної здатності. Далі потрібно розмістити вагони 3 ліквідаційними матеріалами, таким чином щоб аварійно відновлювальний поїзд міг дістатись протягом 30 хвилин, та забрати все необхідне, і швидко дістатись до місця аварії, та приступити, до ліквідації наслідків.

Поряд 3 цим, зафіксована відсутність чіткого сценарію організації ліквідаційних заходів аварій на залізничному транспорті. Не має чіткого алгоритму дій 3 моменту виникнення аварійної ситуації, до повної ліквідації іiі наслідків, що і призводить до екологічних катастроф, та значних економічних витрат.

Згідно з розпорядженням кабінету міністрів України від 30 травня 2018 р. № 430-р., була схвалена «Національна транспортна стратегія України на період до 2030 року» [5] в якій чітко прописано наступні пункти, які стосуються зазначеного питання, а саме:

- приведення нормативно-правових актів у сфері безпеки у відповідність з регламентами та директивами СС стосовно врахування вимог щодо безпечної експлуатації інфраструктури та рухомого складу;

- забезпечення впровадження вимог законодавства $\mathrm{CC}$ у сфері перевезення небезпечних вантажів, у тому числі 3 урахуванням принципів мультимодальності;

- запровадження системи управління безпекою на залізничному транспорті відповідно до законодавства ЄС;

Також, згідно закону України «Про перевезення небезпечних вантажів»[6] та наказом міністерства транспорту України 16.10 .2000 р. № 567 «Про затвердження Правил безпеки та порядку ліквідації наслідків аварійних ситуацій з небезпечними вантажами при перевезенні ї залізничним транспортом» [7]. В яких також прописані вимоги $\mathrm{i}$ для перевезення небезпечних вантажів, i для ліквідацій аварій на залізничному транспорті

Вказані регуляторні законодавчі акти є дуже важливими, адже не виконання їх вимог може призвести до екологічних катастроф та значних економічних втрат.

На рис. 2 наведено приклад розробленої авторами процедури ліквідації наслідків аварії при перевезенні небезпечних вантажів 3 нафтопродуктами.

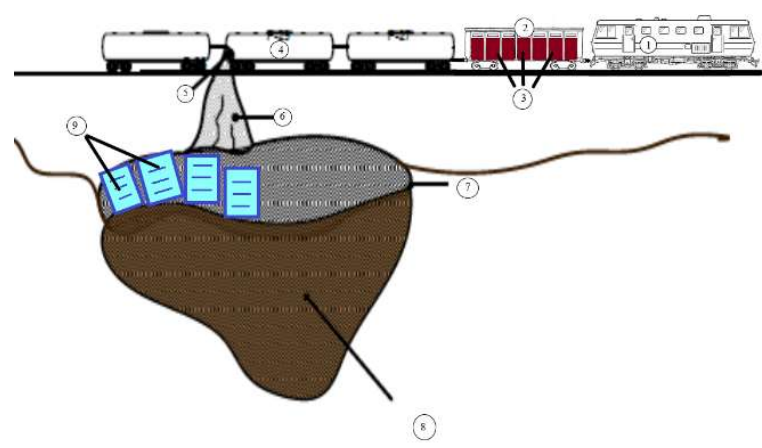

Рис. 2. Візуалізація процедури ліквідації наслідків аварії при перевезенні небезпечних вантажів (нафтопродуктів):

1 - локомотив; 2 - вагон із сорбентом; 3 контейнери з сорбційним покривалом; 4 - чистерна з рідким небезпечним вантажем; 5 - отвір, через який траплясться виток; 6-поверхневий стік рідкого небезпечного вантажу за рельєфом місиевості; 7 - зона утворення дзеркала витоку; 8 зона ураженої товщі трунту; 9 - сорбиійне покривало

Як видно $з$ рис. 2 до поїзда прикріплюється вагон 3 контейнерами із сорбентами (2), і якщо виникає аварійна ситуація при перевезенні небезпечного вантажу, то спеціально навчена людина, що пройшла відповідні спеціальне навчання , та має відповідні сертифікати, відкриває контейнери із сорбентом (3), дістане так звані сорбційні покривала (9), та закидає ними, зону утворення дзеркала витоку (7), для того щоб запобігти потрапляння небезпечного вантажу у товщу грунту, та зменшити зону ураження товщі грунту (8). Потім відпрацьовані сорбенти засовують, назад у контейнера, а по прибуттю поїзда до місця його постійної дислокації, сорбент регенерують, а після регенерації його можна використовувати знову.

Реалізація представленої технологічної схеми дозволяє не тільки отримати оперативний доступ до ліквідаційних матеріалами в зоні утворення і локалізації розливу, але і в значній мірі зекономити час на організацію забезпечення даними матеріалами.

Висока ефективність запропонованого методу забезпечується вибором відповідного сорбенту. Як зазначалося вище, ефективний вибір сорбенту $є$ складним організаційним завданням, що важко реалізовується в оперативних умовах проведення ліквідаційних заходів. Представлена технологічна схема дозволяє вирішити дану проблему завчасно: вибір, придбання i накопичення сорбентів відбувається задовго до виникнення аварійної емісії. 
Для захисту об'єктів навколишнього середовища широко застосовують сорбційні технології - вони ефективні, надійні і прості в апаратному виконанні.

Отже, сорбент [8] - спеціальний матеріал, який за рахунок фізико-хімічних процесів на власній поверхні здатен до поглинання речовин зі зменшенням їх початкової концентрації у вихідному розчині, саме цей механізм забезпечує високу ефективність ліквідаційних заходів на базі сорбційних технологій.

Сучасні сорбенти ділять на [8]:

- вуглецеві адсорбенти на основі природних і синтетичних матеріалів (активоване вугілля, в тому числі таблетовані форми; активовані вуглецеві волокна);

- силикагели;

- цеоліт;

- алюмогелі (альмагель, маалокс);

- алюмосилікати;

- інші неорганічні сорбенти;

- іонообмінні матеріали;

- органомінеральні і композиційні сорбенти;

- рідкі абсорбенти (вода, масла);

- органічні синтетичні і природні сорбенти (полісорб, ентеродез, ентеросорб; лігніни в різних модифікаціях - поліфепан; хітин, хітозан; целюлоза), пектини.

В умовах дефіциту фінансування природоохоронної діяльності все більший інтерес викликають субститути промисловим сорбентам на основі модифікації природних матеріалів і відходів.

В даній роботі був зроблений вибір на користь вуглецевих сорбентів, тому що вони простіші у виконанні та використанні, значно дешевші порівняно 3 іншими сорбентами, та мають досить високий ступінь очищення 95$99 \%$.

На рис. 3 представлено різні варіанти та модифікації матеріалів на основі яких виготовляють вуглецеві сорбенти.

Взагалі, планується розробка універсального сорбенту, як універсального засобу для локалізації та ліквідації наслідків аварій при перевезенні рідких фракцій небезпечних вантажів.

Проаналізувавши всі дев'ять класів небезпечних вантажів, для створення універсального сорбенту авторами було виключено: небезпечні вантажі 1 класу (Вибухові речовини і вироби); 2 класу (Гази); класу 4.1 (Легкозаймисті тверді речовини, самореактивні речовини, речовини, які полімеризуються і тверді десенсибілізовані вибухові речовини), 7 клас (Радіоактивні матеріали), 9 Інші небезпечні речовини та вироби. По-перше, тому що сорбційні методи використовують для ліквідації рідких речовин. По-друге деякі з цих вантажів мають характерні небезпечні, специфічні властивості.

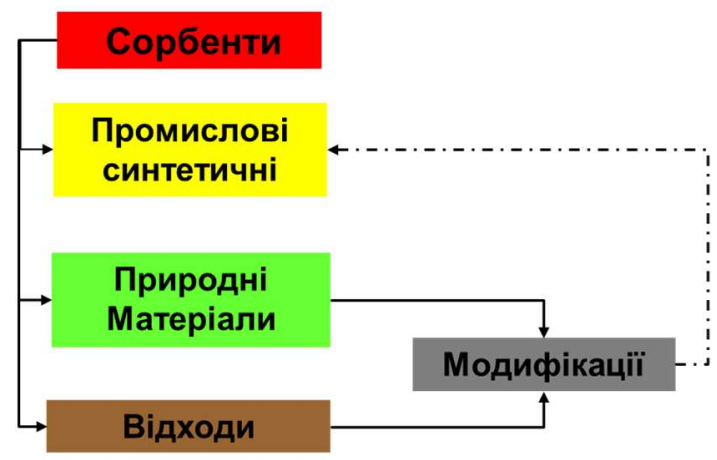

Рис. 3. Різні варіанти та модифікації матеріалів для виготовлення вуглецевих сорбентів

У табл. 1 представлені різні сорбційні матеріали, які використовують для різних класів небезпечних вантажів.

Таблиця 1

Аналіз практики застосування сорбційних матеріалів для різних класів небезпечних вантажів

\begin{tabular}{c|c|c|c|c|c|c|c}
\hline \multicolumn{7}{c}{ Класи небезпеки } \\
\hline Сорбенти & 3 & 4 клас & \multicolumn{2}{c|}{5 клас } & \multicolumn{2}{|c}{6 клас } \\
\cline { 3 - 8 } & клас & 4.2 & 4.3 & 5.1 & 5.2 & 6.1 & 6.2 \\
\hline $\begin{array}{c}\text { Активоване } \\
\text { вугілля }\end{array}$ & + & & & + & + & + & + \\
\hline Пісок & + & & & & & & \\
\hline Вовна & + & & & & & & \\
\hline $\begin{array}{c}\text { Деревна } \\
\text { тріска }\end{array}$ & + & & & + & + & & \\
\hline $\begin{array}{c}\text { Висушені } \\
\text { зернові } \\
\text { продукти }\end{array}$ & & & & & & + & + \\
\hline Макулатура & & & & + & + & &
\end{tabular}

Проаналізувавши дані з таблиці було обрано декілька найбільш ефективних сорбційних матеріалів, а саме: активоване вугілля та відходи деревинної тріски. У якості сировини для виготовлення активованого вугілля [7] пропонується використання відходів кавових зерен фракцією від 0,1 мм до 1 мм. Із відходів деревинної тріски або стружки пропонується використовувати крупну чи мілку тріску або стружку. 


\section{Висновки}

Таким чином, авторами пропонується:

1) переглянути та доопрацювати процедуру перевезення небезпечних вантажів залізничним транспортом (підвищення вимог до персоналу, що виконує операції з небезпечними вантажами, супроводження небезпечних вантажів та удосконалення процедури проведення спеціального навчання).

2) на документальному рівні дозволити залучення аварійно-відновлювальних поїздів до участі у локалізації та ліквідації аварійних наслідків, оснащення вказаних підрозділів необхідним обладнанням для ліквідаційних заходів.

3) удосконалення методики локалізації та ліквідації аварійних наслідків при перевезенні небезпечних вантажів залізничним транспортом - розроблення ситуаційних карт, інструкцій та сценаріїв з елементами моделювання.

4) розробка спеціального сорбенту, як універсального засобу локалізації та ліквідації аварійних наслідків при перевезенні небезпечних вантажів.

Отже, чому автори акцентують увагу на правильному поводженні при перевезенні небезпечних вантажів, та уразі виникнення аварійної ситуації

По-перше, у нашій країні кожен рік трапляються щонайменше 2 аварії на рік, що завдають екологічної шкоди навколишньому середовищу, а також економічні збитки підприємствам.

По-друге, неможливість забезпечення та дотримання правил безпеки при перевезенні небезпечного вантажу, а також при ліквідації наслідків аварій (відсутність чіткого алгоритму дій та взаємодії одних підрозділів 3 іншими, застаріла матеріально технічна база, і.т.п.)

В трете, на правовому рівні не достатньо, або не чітко прописані, урізані повноваження підрозділів, що займаються питаннями перевезення небезпечних вантажів, та ліквідації наслідків аварій при їх перевезенні.

Bce це не дає змогу забезпечити безпеку на транспорті при перевезенні небезпечних вантажів, що призводить до аварійних ситуацій під час їх перевезення.
Зробивши висновки, ми повинні зрозуміти наскільки це важливо дотримуватись усіх правил безпеки, а також дослухатись до порад авторів, які можуть покращити стан справ, у питаннях, перевезенні небезпечних вантажів, їх локалізації, та ліквідації при їх перевезенні.

\section{БІБЛІОГРАФІЧНИЙ СПИСОК}

1. Киселёв И.П., Титова Т.С. Экологические аспекты высокоскоростного железнодорожного транспорта. - СПб.: Петербургский государственный университет путей сообщения, 2005. - 50 с.

2. Павлова Е.И. Экология транспорта. - М.: Транспорт, 2000. - 248 с.

3. Стан справ у сфері перевезенні небезпечних вантажів за 2019 рік у порівнянні з 2018 роком, Директорат з безпеки на транспорті, О. В. Харченко - м. Київ, 2020.

4. «Про затвердження Порядку проведення спеціального навчання працівників суб'єктів перевезення небезпечних вантажів» постанова Кабінету Міністрів України від 31.10.2007 № 1285[Електронний ресурс] - Режим доступу: https://www.kmu.gov.ua/npas/96433179.

5. «Національна транспортна стратегія України на період до 2030 року» розпорядження кабінету міністрів України від 30 травня 2018 р. № 430-р. [Електронний ресурс] - Режим доступу: https://zakon.rada.gov.ua/laws/card/430-2018-p.

6. «Про перевезення небезпечних вантажів» закон України від 06.04.2000 № 1644III[Електронний ресурс] - Режим доступу: https://zakon.rada.gov.ua/laws/card/1644-14.

7. «Про затвердження Правил безпеки та порядку ліквідації наслідків аварійних ситуацій 3 небезпечними вантажами при перевезенні їx залізничним транспортом» наказ міністерства транспорту України 16.10 .2000 p. № 567 Електронний pecypc] - Режим доступу: https://zakon.rada.gov.ua/laws/card/z0857-00.

8. Сорбенты / [Електронний ресурс] - Режим доступу: https://ru.wikipedia.org/wiki/Сорбенты.

9. Розробка інноваційних сорбентів на базі відходів споживання кавової продукції та дослідження їх властивостей: Дипломна Робота / Ю. В. Зеленько, М. В. Калимбет, М.Л. Сорока - м. Дніпро. 2018.

Надійшла до редколегії 25.09.2020

Прийнята до друку 29.10.2020 


\section{ВНЕДРЕНИЕ МЕРОПРИЯТИЙ ПО ЛИКВИДАЦИИ ПОСЛЕДСТВИЙ АВАРИЙ ПРИ ПЕРЕВОЗКЕ ОПАСНЫХ ГРУЗОВ}

В статье описываются проблемы при перевозке опасных грузов, и при ликвидации аварийных последствий при перевозке опасных грузов железнодорожным транспортом. Также представлено решение этих проблем. Цель данного исследования - совершенствование процедуры перевозки опасных грузов железнодорожным транспортом и ликвидационных мероприятий, а также уменьшение временных затрат на ликвидацию аварийных последствий при перевозке опасных грузов железнодорожным транспортом. Методика. В этой статье подробно описывается предложенные авторами предложения по совершенствованию процедуры перевозки опасных грузов, и ликвидационных мероприятий в правовом поле, путём пересмотра полномочий сотрудников, а также путём разработки и использования универсального сорбента из композитных материалов. То есть авторами предлагается разработка универсального сорбента и внедрение его на железнодорожном транспорте. Научная новизна заключается в создании универсального сорбента, который сможет, как одного из ликвидационных мероприятий при аварийных ситуациях при перевозке опасных грузов железнодорожным транспортом. Практическая значимость. В Украине, на железнодорожном транспорте является сорбенты для ликвидации аварий, их очень много, но один сорбент можно использовать только для ликвидации конкретного класса опасности, а наш универсальной сорбент, можно будет использовать для ликвидации нескольких классов опасных грузов. Авторы предлагают его прикрепить к поезду, что позволит сразу приступить к локализации разлива до прибытия аварийно-восстановительного поезда, и таким образом уменьшит драгоценное время на ликвидационные мероприятия. Так же расширение полномочий некоторых подразделений позволит уменьшить количество аварийных ситуаций, и последствия при локализации и ликвидаций аварий при перевозке опасных грузов.

Ключевые слова: экологические технологии; опасные грузы; локализация аварий; специальное обучение; универсальный сорбент; аварийно-восстановительные поезда

\section{Y. ZELENKO, M. KALYMBET, D. FESENKO}

\section{IMPLEMENTATION OF MEASURES TO ELIMINATE THE CONSEQUENCES OF ACCIDENTS DURING THE TRANSPORTATION OF DANGEROUS GOODS}

The article describes the problems during the transportation of dangerous goods, and during the elimination of accidents during the transportation of dangerous goods by rail. The solution of these problems is also presented. The purpose of this study is primarily to improve the procedure for transportation of dangerous goods by rail, and liquidation measures, as well as to reduce the time spent on the elimination of accidents during the transportation of dangerous goods by rail. Method. This article describes in detail the proposals proposed by the authors to improve the procedure for transportation of dangerous goods, and liquidation measures in the legal field, by reviewing the powers of employees, as well as by developing and using a universal sorbent of composite materials. That is, the authors propose the development of a universal sorbent and its introduction in railway transport. The scientific novelty is the creation of a universal sorbent, which will be able as one of the liquidation measures in emergency situations during the transportation of dangerous goods by rail. Practical significance. In Ukraine, there are many sorbents on rail transport to eliminate accidents, there are many, but one sorbent can be used only to eliminate a specific class of danger, and our universal sorbent can be used to eliminate several classes of dangerous goods. The authors propose to attach it to the train, which will allow to immediately start the localization of the spill before the arrival of the emergency recovery train, and thus reduce the precious time for liquidation measures. when transporting dangerous goods.

Key words: environmental technologies; dangerous goods; localization of accidents; special training; universal sorbent; emergency recovery trains 